УДК $341.1 / .8$

DOI https://doi.org/10.32837/pyuv.v0i5(34).667

O.C.Савич

orcid.org/0000-0002-0435-2818

кандидат юридичних наук, доцент,

доцент кафедри морського права

Національного університету «Одеська морська академія»

К. В. Дудніченко

orcid.org/0000-0003-0727-5480

студент магістратури

Навчально-наукового інституту морського права та менеджленту

Національного університету «Одеська морська академія»

\title{
ПРАВОВЕ РЕГУЛЮВАННЯ УТИЛІЗАЦІЇ СУДЕН
}

Постановка проблеми. Морське або річкове судно є джерелом підвищеної небезпеки та має свій термін експлуатації. Після закінчення безпечного терміну експлуатації неминуче постає питання його утилізації, а безпечна та нешкідлива утилізація морських суден $є$ вкрай актуальною. Закінчення терміну експлуатації судна породжує певні ризики: фінансові затрати судновласника на утримання старого судна, забруднення навколишнього природнього середовища, загроза життю та здоров'ю людей.

Ненормований та безконтрольний процес утилізації суден призводить до шкоди як довкіллю, так і людям, які задіяні під час утилізації та які живуть біля місць утилізації.

Актуальними є питання нормативної регламентації утилізації морських/річкових суден, формування техніко-юридичних стандартів на міжнародному рівні та їх впровадження на внутрішньодержавному рівні.

Метою статті $є$ аналіз стану правової регламентації утилізації морських/річкових суден.

Аналіз останніх досліджень та публікацій. Питання утилізації суден у науковій літературі вивчається переважно з технічної, економічної або екологічної точок зору. Юридичні питання зазначеної проблематики не розкриваються, або містяться згадки в незначній кількості в роботах вітчизняних та зарубіжних науковців.

Тематиці утилізації суден присвячені роботи таких зарубіжних авторів: A. Kelly, J.P. Mallory, K. John, J.W. Bull, R. Goy, A. Lilar, C. Van Den Bosch, C.P. Srivastava, F. Bowen, C. Chanew, P. Gwin, M. Fahsi, B. Tuncak та вітчизняних науковців: Л.В. Пізінцалі, В.С. Наумова, И.Б. Кочнева.

Виклад основного матеріалу. Правова регламентація питання утилізації суден відбувається на декількох рівнях: міжнародному, регіональному, національному. На міжнародному рівні розробленням профільних нормативних актів 3 утилізації суден займаються Міжнародна морська організація та Організація Об’єднаних Націй.
У 70-80-х роках, після декількох морських катастроф світова спільнота наполягала на забороні вільної торгівлі небезпечними відходами. У рамках екологічної програми ЮНЕП було прийнято Базельську конвенцію про контроль за транскордонним перевезенням небезпечних відходів та їх видаленням, яка є обов'язковою, її ратифікували більше 170-ти країн.

Базельська конвенція про контроль за транскордонним перевезенням небезпечних відходів та їх видаленням від 22 березня 1989 року є міжнародним договором, який був підготовлений для скорочення руху небезпечних відходів у країнах i для запобігання неконтрольованій утилізації небезпечних відходів у країнах, що розвиваються. Конвенція має на меті зменшити кількість і токсичність зібраних відходів, щоб упровадити екологічно безпечне управління ними якомога ближче до джерела виробництва та надати допомогу країнам, що розвиваються, з екологічно безпечного керівництва небезпечними та іншими відходами, які вони створюють [1].

У 1995 році було створено поправку до Базельської конвенції про заборону. Поправка забороняє вивезення небезпечних відходів з більш розвинених до менш розвинених країн. Поправка набула чинності 5 грудня 2019 року та була перенесена в законодавство Союзу Регламентом Європейського Союзу про відвантаження відходів (ЄC WSR). Експорт небезпечних відходів з ЄС до країн, що розвиваються, заборонено [2].

Цікавим є визначення терміна «судно» в Базельській конвенції. Термін «судно» визначається як небезпечні відходи через їхні токсичні компоненти, такі як азбест, свинець та ртуть. Цікавим є те, що таке визначення судна характерно лише для цієї конвенції. Як відмічає О.М. Шемякін, «у морському праві термін «судно» розкривається тільки стосовно мети конкретного правового акта» [3, с. 52].

Також Конвенція наголошує: «Відходи, що виникають у результаті нормального функціонування 
морських суден, скидання яких охоплюється іншими міжнародно-правовими документами, виключаються зі сфери дії цієї Конвенції» (стаття 1) [1].

Незважаючи на те, що Базельська конвенція $\epsilon$ величезним виграшем для екологічної справедливості, в застосуванні їі положень щодо суден виникли труднощі. Багато європейських суден опиняються на пляжах Південної Азії, незважаючи на Базельську конвенцію, включаючи поправку про заборону, яка застосовується в ЄС. Сторони визнали, що Базельський контроль більшість цих випадків обходить стороною. Оскільки судно стає відходом лише тоді, коли наміри утилізувати його очевидні, власникам суден достатньо сховати свої справжні наміри від місцевих органів влади [4]. Дійсно, судноплавні компанії часто помилково заперечують, що судна призначені для злому, і натомість заявляють, що судно прямує до ремонту в док або продане для подальшого експлуатаційного використання.

Базельська конвенція також стояла на суті важливих рішень, таких як постанова Верховного суду 2009 року в Бангладеш, яка закрила всю галузь, оскільки вона не працювала відповідно до чинного національного та міжнародного екологічного законодавства. В Свропі експорт суден до пляжних доків був припинений на основі вимог ЄC WSR. Підвищена обізнаність із каламутним бізнесом щодо токсичної торгівлі суднами призвела до кількох розслідувань, що тривають, i в 2018 році в Нідерландах власник судна вперше був притягнутий до кримінальної відповідальності за те, що мав намір утилізувати чотири судна на пляжі в Індії [5].

Україна теж ратифікувала Базельську конвенцію про контроль за транскордонним перевезенням небезпечних відходів та їх видаленням [6]. Також в Україні є деякі підприємства, які займаються утилізацією небезпечних відходів та морських транспортних засобів, але статистика щодо цієї діяльності відсутня.

У 2002 році секретаріатом Базельської конвенції були розроблені Технічні вказівки щодо екологічно безпечного регулювання повного та часткового демонтажу суден. Вони носять рекомендаційний характер. Документ було видано 1 січня 2003 року для країн, які вже мають або створюють об'єкти для утилізації суден. Настанови містять рекомендації щодо процедур, процесів та практик, які необхідно застосовувати для забезпечення безпечної та екологічно безпечної практики.

Наразі ці Рекомендації не стосуються заходів щодо мінімізації небезпечних матеріалів, які знаходяться на борту суднаперед тим, як їх відправити на об'єкт з переробки суден. Взагалі, Рекомендації обмежуються технічними та процедурними аспектами демонтажу судна. Зрозуміло, що юридичні питання щодо експорту суден як небезпечних відходів все ще мають бути вивчені Юридичною робочою групою Базельської конвенції.

Дана Резолюція розроблена для надання рекомендацій усім зацікавленим сторонам у процесі утилізації суден. До них відносяться держави прапора, порту й утилізації, влади суднобудівних країн і країн, що постачають суднове обладнання, а також відповідні міжурядові організації та комерційні органи, такі як власники суден, суднобудівні верфі, заводи-виробники суднового устаткування, ремонтні та утилізаційні підприємства [7]. До додаткових зацікавлених сторін відносяться робочі, місцеві спільноти, екологічні та трудові організації.

У Резолюції визначаються: що відноситься до потенційно небезпечних матеріалів; наявність «зеленого паспорта» для судна; процедури, що стосуються нових суден щодо утилізації; процедури, що стосуються існуючих суден щодо утилізації [7].

У 2009 році в Гонконзі було прийнято Гонконгську конвенцію Міжнародної морської організації (IMO) про безпечну та екологічно безпечну утилізацію суден. Конвенція встановлює стандарти щодо переробки суден та покладає відповідальність за виконання за державою прапора судна та державою переробки. Створенню Конвенції передувало прийняття у 2003 р. Асамблеєю IMO Керівництва 3 розбирання суден і потім прийняття у 2005 р. 24-ю сесією Асамблеї ІМО рішення про необхідність розроблення обов'язкового інструменту для глобального застосування.

Згідно зі ст. 3 Конвенція застосовується до «суден 500 і більше тонн» [8].

Конвенція не застосовується «до військових кораблів, військових допоміжних суден, а також суден, що використовуються для державної некомерційної служби.

Конвенція також не застосовується до суден, що працюють увесь термін служби у водах, що знаходяться під юрисдикцією держави, прапор якої вони несуть» [8].

Конвенція вводить поняття «Ship recycling facility» (стаття 2 Визначення) [8], яке українською мовою дослівно перекласти неможливо. Дане словосполучення означає територію, яка $\epsilon$ майданчиком, доком або спорудою, що використовується для утилізації суден. Тому найбільш точним перекладом ми пропонуємо визначити як «об'єкти з утилізації суден», які будуть саме включати всі місця, де будуть утилізуватись судна: доки, верфі, споруди та інше.

Особливу увагу Конвенція приділяє інспектуванню судна, яке буде утилізуватись або ще виконує рейси. У Додатку до Конвенції, який називається Рекомендації до безпечної та екологічної утилізації суден, є перелік необхідних процедур для об’єктів з утилізації суден та до суден, які будуть утилізуватись. 
Конвенція ще не вступила в силу. Через це Міжнародна морська організація на базі Конвенції 2009 року створила декілька Резолюцій з утилізації суден, які фактично копіюють зміст Конвенції, тому що всі пункти та розділи Резолюцій знаходяться в Додатку до Конвенції. Проблема полягає в тому, що Резолюції носять лише рекомендаційний характер, і держави цих настанов можуть також не дотримуватися, але вони все одно є та діють.

РезолюціяIMOМЕРС.196(62)-керівництвазрозроблення плану переробки суден (прийнята 15 липня 2011 року), Резолюція МЕРС.210 (63) - вказівки 3 безпеки та екологічної утилізації суден (прийнята 2 березня 2012 року), Резолюція МЕРС.211(63) - рекомендації з авторизації об'єктів з утилізації суден (прийнята 2 березня 2012 року), Резолюція МЕРС 269(68) - Керівні принципи розроблення інвентаризації небезпечних матеріалів (прийнята 15 травня 2015 року), Резолюція МЕРС.222 (64) - рекомендації для обстеження/огляду та сертифікації суден за Гонконгською конвенцією (прийнята 15 жовтня 2012 року), Резолюція МЕРС.223 (64) - вказівки до інспекції суден за Гонконгською конвенцією (прийнята 5 жовтня 2012 року).

На регіональному рівні яскраво представлені акти Європейського союзу. Європейський Парламент та Рада Європейського Союзу прийняли Регламент з утилізації суден (EU SRR) 20 листопада 2013 року. Метою Регламенту є зниження негативних наслідків, пов'язаних з утилізацією суден.

331 грудня 2018 року комерційні судна під прапором $\mathrm{CC}$ понад $500 \mathrm{GT}$ повинні бути перероблені на безпечних і екологічно безпечних підприємствах з утилізації суден, які включені до Європейського списку затверджених підприємств з утилізації суден [9]. Список був уперше складений 19 грудня 2016 року і періодично оновлюється для додавання додаткових відповідних коштів або виступає альтернативою для видалення об'єктів, які перестали відповідати. Список включає об'єкти, що діють у глобальному масштабі [10].

Для включення в Європейський список будьяке підприємство з утилізації суден незалежно від його місця розташування має відповідати низці вимог безпеки й охорони навколишнього середовища. Список вимог дуже жорсткий та більш розширений, ніж у Гонконгській Конвенції. Так, у статті 13 визначено: щоби бути включеним до Європейського списку, об'єкт з переробки суден повинен відповідати певним вимогам відповідно до положень Конвенції Гонконгу та з урахуванням відповідних керівних принципів IMO, МОП, Базельської конвенції та інших міжнародних керівних принципів, а саме: «він (об’єкт) спроектований, побудований та експлуатується безпечно та екологічно безпечно; встановлюе системи управління, моніторингу, процедури та методи, які ма- ють на меті запобігання, зменшення, мінімізацію та, наскільки це можливо, усунення ризиків для здоров'я зацікавлених робітників та населення в околицях підприємства 3 переробки суден та шкідливий вплив на навколишнє середовище, спричинений переробкою суден...»; та особливо, що «він встановлює та підтримує план готовності та реагування на надзвичайні ситуації; забезпечує швидкий доступ обладнання для реагування на надзвичайні ситуації, такого як обладнання для пожежогасіння та транспортні засоби, машини швидкої допомоги та крани, до судна та всіх районів устаткування для переробки суден...» [11].

Саме в Регламенті зазначено, що «він (об’єкт) передбачає безпеку та навчання працівників, включаючи забезпечення використання засобів індивідуального захисту для операцій, що вимагають такого використання...», і це не вказано в Гонконгській Конвенції [11]. Особливу увагу приділяють тому, що «він (об'єкт) установлює облік інцидентів, нещасних випадків, професійних захворювань та хронічних наслідків і на запит компетентних органів повідомляє про будь-які інциденти, нещасні випадки, професійні захворювання чи хронічні наслідки, що спричиняють або можуть спричинити ризики для безпеки працівників, здоров'я людей та довкілля». Дана інформація має бути у відкритому доступі [11].

Об'єкти, що діють в ЄС, затверджені їхніми національними органами для внесення в список. Європейська комісія оцінює заявки, отримані від підприємств з утилізації суден, розташованих у третіх країнах. Список ЄС функціонує як важливий диференціатор ринку для дворів, які вже вклали кошти в належні стандарти безпеки та охорони праці.

Хоча в Регламенті викладені вимоги Гонконгської конвенції 2009 року про безпечну та екологічно обґрунтовану утилізацію суден, в нього також включені додаткові вимоги з безпеки й охорони навколишнього середовища. Дійсно, ЄС установлює більш високі стандарти, ніж Гонконгська конвенція IMO - метод пляжного розміщення заборонений, і в нього включені вимоги, що стосуються поводження з токсичними відходами вниз за течією, а також трудових прав. Крім того, підприємства з переробки суден, включені в списки $\mathrm{\epsilon C}$, піддаються більш ретельному контролю: незалежна сертифікація і аудит третьої сторони можуть подавати скарги, якщо в них є побоювання, що вказане підприємство не працює відповідно до Регламенту. Це важливі гарантії, які відсутні за режиму Гонконгської конвенції. Перелік ЄС дійсно є єдиною гарантією того, що двір був незалежно сертифікований і перевірений на відповідність прийнятним стандартам [11].

331 грудня 2018 року великі комерційні морські судна, що плавають під прапором держави 
члена $\mathrm{EC}$, можуть перероблятися лише в безпечних та надійних установках для переробки суден, включених до Європейського переліку об'єктів для переробки суден («Європейський список»).

Європейський список був уперше створений 19 грудня 2016 року та востаннє оновлений 22 січня 2020 року. Зараз він містить 41 док, включаючи 34 об'єкти, розташовані у 12 країнахчленах $€$ с та в Норвегії, 6 об'єктів у Туреччині та 1 об'єкт у Сполучених Штатах Америки [10].

Щоб бути включеним до Європейського списку, будь-який завод із переробки суден незалежно від його місцезнаходження повинен відповідати ряду вимог безпеки та екології. У квітні 2016 року Комісія видала технічні вказівки щодо цих вимог [10].

Аналіз Європейського переліку країн, які займаються утилізацією суден, довів, що лише Туреччина утилізує судна пляжним способом [10].

Для того щоб забезпечити утилізацію суден в Україні, судновласнику насамперед необхідно здійснити вибір організації, яка зробить фізичне знищення судна. Слід зазначити, що компанії, які спеціалізуються на утилізації суден, повинні відповідати певним вимогам, зокрема Закону України «Про відходи», а також мати ліцензію на заготівлю, зберігання, переробку і реалізацію лому чорних металів, кольорових металів, але відповідно до Закону України «Про ліцензування видів господарської діяльності» у 2019 році пункт, що дана діяльність повинна мати ліцензію, був виключений (пункт 16 , статті $166^{12}$ ) [12]. Також у Законі України «Про металобрухт» зазначено: "Діяльність, пов'язана із заготівлею, переробкою брухту чорних та кольорових металів і його металургійною переробкою, провадиться в порядку, встановленому законодавством...." (стаття 4), а пункт про видачу ліцензії був скасований [13]. Але в Україні немає чіткої інструкції та нормативного-правового акта, який би пояснював, як потрібно утилізувати судно, та які вимоги висуваються до підприємства, котре буде займатися утилізацією [14].

В Україні утилізацією морського транспорту займається компанія «УтільВторПром», однак про конкретну процедуру для утилізації суден інформації немає.

У такому документі Регістру судноплавства України, як «Правила класифікації та побудови суден частина i. Класифікація. Правила по запобіганню забрудненню з суден. Бюлетень № 4 змін і доповнень» від 2020 року є лише відсилки до процесу утилізації суден в Україні, які повинні були доповнитись до «Правил по запобіганню суден» [15].

Тому в документі «Правила запобігання забрудненню з суден» від Регістру судноплавства України зазначено, що згідно з пунктом 5.3.12.1. «Усі судна повинні мати Посвідчення відповідності резолюції IMO по утилізації суден «Зелений паспорт» згідно з Керівництвом IMO по утилізації суден (див. резолюцію А.962(23) з додатками і поправками, прийнятими на даний час)» [16], а пункт 5.3.12.2. приписує: «Вищевказане Посвідчення з Додатком повинно постійно перебувати на борту судна протягом усього терміну його експлуатації. Для збереження достовірності інформації судновласник повинен постійно проводити роботу щодо актуалізації документа, вносити в Доповнення всі важливі зміни конструкції і обладнання судна» [16]. Даний документ є вираженням норми м'якого права, а саме Резолюції IMO 2003 року, і тому пункт 5.3.12.1 та пункт 5.3.12.1 мають юридичну силу і повинні виконуватись, але цього недостатньо, щоб в Україні впровадити сферу з утилізації суден.

Л.В. Пізінцалі зазначає: «Розвиток галузі з утилізації морського і залізничного транспорту, безсумнівно, збільшить потребу судноплавних компаній i «Укрзалізниці» в оновленні флоту, що потребують реновації існуючих українських вагонобудівельних і суднобудівних підприємств...», тому, безумовно, потрібно розвивати в Україні дану сферу [17]. Л.В. Пізінцалі з технічної точки зору зазначає, що для створення сучасного утилізаційного підприємства в Україні необхідні «розроблення технології оброблення корпусних частин, конкурентоспроможної за критеріями економічності та екологічності; наявність системи оцінки технічного стану та відновлення залізничного і морського транспорту; організація ринку «second hand» деталей, запасних частин, меблів, сантехніки, пристроїв тощо» [17]. Але для введення цих пунктів необхідна юридична сторона та підтримка з боку держави.

Висновки. На міжнародному рівні була прийнята низка актів 3 питань утилізації суден. Для максимально повної та ефективної правової бази необхідно, щоб Гонконгська Конвенція вступила в силу. Це дасть правильний контроль за процесом утилізації в тих країнах, де відбувається повна екологічна катастрофа (Індія та Бангладеш). Варто відмітити наявність в Європейському Союзі Регламенту 2013 року з утилізації суден, який обов'язково стає частиною законодавства тих країн, що займаються утилізацією суден, а таким чином, утилізація стає безпечною та екологічною.

Для нормальної регуляції та впровадження сфери утилізації суден в Україні потрібно провести великий комплекс робіт. Наприклад, треба ратифікувати Конвенцію IMO про безпечну та екологічно безпечну утилізацію суден (Гонконгська конвенція 2009 р.) та Регламент Європейського Союзу з утилізації суден, для того щоб об'єкти 3 утилізації суден України були внесені до Європейського списку з утилізації суден; розробити закони та стандарти для безпечної утилізації суден в Україні, яких взагалі немає 
в Україні натепер; розробити програму дотацій для підприємств України, на яких будуть утилізуватися українські судна; привести верфі в придатний до безпечної утилізації суден стан або відвести спеціальні місця для утилізації суден; повернути видачу ліцензій для підприємств, які займаються утилізацією небезпечних відходів, для контролю за цими підприємствами, щоб запобігти екологічній катастрофі.

\section{Jimepamypa}

1. Базельська конвенція про контроль за транскордонним перевезенням небезпечних відходів та їх видаленням 22.03.1989 p. База даних «Законодавство України» / ВР України. URL: https://zakon.rada.gov.ua/laws/show/995 022 (дата звернення: 11.09.2020).

2. History of the negotiations of the Basel Convention. URL: http://www.basel.int/TheConvention/ Overview/History/Overview/tabid/3405/Default.aspx

3. Шемякин А.Н. Морское право : учебное пособие, 2-е издание. ВМВ, 2006. 437 с

4. Ngo shipbreaking platform. Basel Convention. URL: https://shipbreakingplatform.org/issues-ofinterest/the-law/basel-convention/

5. Parties to the Basel Convention on the Control of Transboundary Movements of Hazardous Wastes and their Disposal. 5 May 1992, No. 28911. URL: http://www.basel.int/?tabid=4499

6. Про приєднання України до Базельської конвенції про контроль за транскордонними перевезеннями небезпечних відходів та їх видаленням : Закон України від 1.07.1999 року. № 803 XIV. URL: https: / / zakon.rada.gov.ua/laws / show / 803-14\#Text (дата звернення: 25.09.2020).

7. Резолюція А.962 (23) Керівництво IMO з утилізації суден. 2003. URL: http://rise.odessa.ua/texts/ A962_23_03.php3 (дата звернення: 11.09.2020).

8. ${ }^{-}$Hong Kong international convention for the safe and environmentally sound recycling of ships. 2009. URL: http://www.basel.int/Portals/4/Basel $\% 20$ Convention/docs/ships/HongKongConvention.pdf

9. Ship recycling: reducing human and environmental impacts: Science for Environment Policy. URL: https://ec.europa.eu/environment/integration/ research/newsalert/pdf/ship_recycling_reducing_ human and environmental impacts 55 si en.pdf

10. Commission Implementing Décision $2020 / 1675$ of 11 November 2020 amending Implementing Decision (EU) 2016/2323 establishing the European List of ship recycling facilities pursuant to Regulation (EU) No $1257 / 2013$ of the European Parliament and of the Council (Text with EEA relevance). URL: https://eurlex.europa.eu/legalcontent/EN/TXT/? uri $=$ CELEX $\%$ 3A32020D1675\&qid $=1605170136460$

11. Resolution MEPC.269(68) 2015 guidelines for the development of the inventory of hazardous materials, Adopted on 15 May 2015. ANNEX 17.

12. Про ліцензування видів господарської діяльності : Закон України від 2.03.2015 року № 222-VIII. URL: https://zakon.rada.gov.ua/laws/ show/222-19\#Text (дата звернення: 20.11.2020).

13. Про металобрухт : Закон України від 5.05.1999 року № № 619-XIV. URL: https://zakon.rada.gov.ua/ laws/show/619-14\#Text (дата звернення: 11.10.2020).

14. Про відходи : Закон України від 05.03.1998. № 187/98-BP. URL: https://zakon.rada.gov.ua/ laws/show / $187 / 98$ - \% D0\% B2\% D1\% 80\#Text (дата звернення: 07.09.2020).

15. Правила класифікації та побудови суден, частина I. Класифікація. Правила по запобіганню забрудненню з суден: Бюлетень № 4 змін і доповнень. Регістр судноплавства України від 2020 p. URL: file: / / C: / Users / Lapstore / Downloads / Telegram\% 20Desktop/Marpol4.pdf

16. Правила запобігання забрудненню 3 суден. Регістр судноплавства України від 2020 p. URL: http://www.shipregister.ua/books/Marpol.pdf (дата звернення: 11.09.2020).

17. Пизинцали Л.В. Предпосылки развития системы утилизации лома в Украине на примере железнодорожного и морского транспорта. Збірник наукових праць ДонІЗТ. 2014 № 37. С. 157-162.

\section{Анотація}

Савич О. С., Дудніченко К. В. Правове регулювання утилізації суден. - Стаття

Статтю присвячено аналізу стану правової регламентації утилізації суден. Утилізація судна є частиною його життєвого циклу. Ненормований та безконтрольний процес утилізації суден призводить до шкоди як довкіллю, так і людям, які задіяні під час утилізації та які живуть біля місць утилізації.

Важливим $€$ формування міжнародних стандартів з питань утилізації суден та їх впровадження на національному рівні. Аналізуються нормативні акти на трьох рівнях: міжнародному, регіональному, національному. На міжнародному аналізуються такі акти: Базельська конвенція про контроль за транскордонним перевезенням небезпечних відходів 1989 р., Технічні вказівки щодо екологічно безпечного регулювання повного та часткового демонтажу суден 2002 р., Резолюція А.962 (23) Керівництво IMO 3 утилізації суден 2003 р., Гонконгська конвенція про безпечну та екологічно безпечну утилізацію суден 2009 р., Резолюція IMO MEPC 196(62) - керівництва з розробки плану переробки суден 2011 р., Резолюція МЕРС 210(63) - вказівки безпеки та екологічної утилізації суден 2012 р., Резолюція MEPC 211 (63) - рекомендації з авторизації об'єктів 3 утилізації суден 2012 р., Резолюція МЕРС 269(68) Керівні принципи розробки інвентаризації небезпечних матеріалів 2015 р., Резолюція МЕРС 222 (64) - рекомендації для обстеження/огляду та сертифікації суден за Гонконгською конвенцією 2012 р. На регіональному рівні аналізуються такі акти: Регламент ЄС по утилізації суден 2013 р., Європейський перелік об'єктів переробки суден 2018 р., Технічні вказівки щодо екологічно безпечного регулювання повного та часткового демонтажу суден 2003 р. та інші. Також увагу приділено стану утилізації суден в Україні та визначено такі шляхи розвитку в окресленій сфері: ратифікація Конвенції IMO про безпечну та екологічно безпечну утилізацію суден та Регламенту Свропейського Союзу з утилізації суден; розроблення та прийняття законів і стандартів для безпечної утилізації суден в Україні; розроблення програм дотацій для підприємств України, на яких будуть утилізуватися українські судна; приведення верфі у придатний до безпечної утилізації суден стан або відведення спеціальних місць для утилізації суден; повернення видачі ліцензій для підприємств, які займаються утилізацією небезпечних відходів, для контролю за цими підприємствами.

Ключові слова: морське/річкове судно, експлуатація суден, морський транспорт, утилізація суден, Базельська конвенція, Гонконгська конвенція, європейський список. 


\section{Summary}

Savych O. S., Dudnichenko K. V. Legal regulation of ship recycling. - Article.

The article is devoted to the analysis of the state of legal regulation of ship recycling. Recycling of a vessel is part of its life cycle. The unregulated and uncontrolled process of ship recycling leads to damage to both the environment and the people involved in the recycling and who live near the recycling sites. It is important to develop international standards for ship recycling and implementation at the national level. Regulations are analyzed at three levels: internation$\mathrm{al}$, regional, national. The following acts are being analyzed internationally: Basel Convention on the Control of Transboundary Movements of Hazardous Wastes, 1989, Technical Guidelines for the Environmentally Sound Management of Full and Partial Dismantling of Ships, 2002, Resolution A.962 (23) IMO Guidelines for Ship Recycling, 2003 Hong Kong Convention Safe and Environmentally Safe Recycling of Vessels 2009, IMO Resolution MEPC.196 (62) - Guidelines for the Development of a Ship Recycling Plan 2011, Resolution MEPC.210 (63) - Guidelines for Safety and Environmental Disposal of Ships 2012, MEPC Resolution. 211 (63) - recommendations for the authorization of ship recycling facilities in 2012, MEPC Resolution 269 (68) -
Guidelines for the development of an inventory of hazardous materials in 2015, Resolution MEPC.222 (64) - recommendations for inspection/inspection and certification of ships under the Hong Kong Convention of 2012. The following acts are analyzed at the regional level: EU Regulation on the Recycling of Ships 2013, European List of Ship Recycling Facilities 2018, Technical guidelines for environmentally friendly regulation of complete and partial dismantling of vessels. 2003 and others. Attention is also paid to the state of ship recycling in Ukraine and the definition of ways of development in this area. Examples such as: ratification of the IMO Hong Kong Convention on the Safe and Environmentally Sound of Ship's Recycling and the European Union Regulation on the Ship's Recycling; development and adoption of laws and standards for safe disposal of ships in Ukraine; development of subsidy programs for Ukrainian enterprises, which will recycle Ukrainian vessels; bringing to the shipyard suitable for safe disposal of ships, or allocation of special places for ship's recycling; return of licenses for enterprises engaged in the disposal of hazardous waste to control these enterprises.

Key words: sea/river vessel, ship operation, maritime transport, ship recycling, Basel Convention, Hong Kong Convention, European list. 